\title{
Women's Perceptions of Graduate Level Educational Administration Programs ${ }^{\dagger}$
}

\author{
JUANITA ROSS EPP*
}

\begin{abstract}
Women in graduate programs have, in the past, been subject to a "chilly climate" (Hall \& Sandler, 1982). Those in educational administration faced particular problems associated with the male orientation of the discipline (Edson, 1988). Has this diminished now that half of the students are women? Although there were many positive reports, the overall experiences for women in educational administration programs were often marred by discriminatory attitudes displayed by specific professors, negative responses to affirmative action initiatives voiced by fellow students, and resentment displayed by both male professors and male students toward female professors. In the students' perceptions, universities had done little to encourage women, although some had been able to take educational administration courses intended to address issues of gender or women's studies courses as part of program. Positive experiences were often associated with exposure to women mentors interested in qualitative research methods. Students' recommendations for improvement of educational administration programs centred around the inclusion of women in course content, the "upgrading" of particularly entrenched professors, and program changes to provide more flexibility. Students were also concerned with changing the school systems themselves, in order to improve job opportunities once they had completed their programs.
\end{abstract}

* Lakehead University

$\dagger$ Thank you to Elaine Hogard for her expert research assistance. 


\section{Résumé}

Les femmes inscrites dans des programmes d'études supérieures ont souvent, dans le passé, été soumises à des conditions décrites comme étant "glaciales" (Hall et Sandler, 1982). Les étudiantes des programmes en administration scolaire semblent rencontrer des difficultés particulières liées à l'orientation masculine de la discipline (Edson, 1988). Cette situation a-t-elle évolué maintenant que les femmes constituent la moitié de la clientèle inscrite à ces programmes? Bien que la situation se soit améliorée, les expériences générales des étudiantes indiquent qu'elles sont toujours marquées par des attitudes discriminatoires de la part de certains professeurs, par des réactions négatives de la part de certains étudiants envers les mesures établies pour promouvoir l'accès à l'égalité, et par le ressentiment porté par les professeurs et les étudiants de sexe masculin envers les professeurs de sexe féminin. De plus, les femmes perçoivent généralement que les établissements d'enseignement supérieur ont peu contribué à faciliter leur expérience universitaire bien que quelques-unes ont pu se prévaloir de cours spécifiques portant sur des questions touchant l'expérience des femmes dans le cadre de leur programme d'étude. Les expériences positives des étudiantes étaient souvent liées au contact avec des professeurs qui agissaient comme mentors et qui s'intéressaient particulièrement aux méthodes qualitatives de recherche. Pour améliorer les programmes d'étude, les étudiantes recommandent d'intégrer la vision des femmes dans les contenus de cours, de faire évoluer les professeurs retranchés dans des attitudes discriminatoires, et de changer les programmes afin de les rendre plus flexibles. Les étudiantes mentionnent également la nécessité de changer le système scolaire afin de bénéficier de meilleures perspectives d'emploi.

Is there still a "chilly climate" for women in graduate programs in educational administration? In the past, the few women who enrolled in these programs faced discrimination, dealt with harassment, felt ignored by the literature, and were discouraged by a sense of invisibility (Edson, 1988; Marshall, 1984; Shakeshaft, 1989). Now two-thirds (67\%) of the graduate students in education are female (Government of Canada, 1992), and there is more awareness about the "genderedness" of organizational theory (Calas \& Smircich, 1992, p. 230). But has this translated into a warmer climate for female students of educational administration? This study was done to assess the present realities of some women's experiences. 
Educational Administration Programs

\section{The Way We Were}

The literature on this topic falls into two categories: studies of women graduate students in general; and those concerned specifically with women in educational administration.

\section{Women in Graduate Programs}

The "chilly classroom climate" for women in universities was documented by Hall and Sandler in several papers between 1982 and 1986. They found that more women were entering institutions of higher learning, but they were not receiving equal treatment:

It would seem that these programs serve more to preserve, rather than to reduce stereotypic differences between men and women in behavior, personality, aspirations and achievement. Faculty behaviors which express different expectations for women ... or which lead women to feel their academic and career ambitions are not as important as those of men students may play a major role in limiting women students' development (Hall \& Sandler, 1982, p. 2).

Hall and Sandler (1982) identified "frosty indicators", especially in male professors' language use. Sexist terminology was being used to disparage (a) women in general, (b) women's intellectual ability, (c) women's seriousness and/or academic commitment, (d) scholarship about women, or about women's perceptions or feelings, or (e) women faculty members and their accomplishments. Some professors displayed sexism by trivializing discussion of students' work by interrupting them to comment on appearance, physical attributes or dress. Others demeaned women's adult capabilities by referring to male students as "men" but female students as "girls" (Hall \& Sandler, 1982, p. 6). A summarized list of further indicators included:

1) interrupting women more than men in seminar discussions;

2) using sexist humour;

3) engaging in more eye contact with male students, thereby inviting responses from men more than from women;

4) ... contacting men students when publication, research and other professional opportunities arise;

5) calling upon women students less frequently ... in a class;

6) better recall and use of the names of men students;

8) steering women away from participation in non-traditional fields; 
9) asking women students lower order questions and/or in general expecting less from women students;

10). . .tend(ing) to devalue women and their work - trivializ(ing) their contributions;

11) maintain(ing) an argumentative, competitive, abstract and impersonal interactive style; and

12) attributing female success to luck or a low level of task difficulty while male success is attributed to skill or ability (Pyke, 1991, p. 7).

These "frosty" incidents affected women in various negative ways. They served to discourage women from classroom participation, prevented them from seeking help from professors, caused them to drop classes or switch majors, minimized their relationships with faculty who would later provide letters of recommendation, dampened career aspirations and undermined confidence (Hall \& Sandler, 1982, p. 3). Women usually took longer than men to finish their master's degrees, were less likely to continue on to doctoral work, and were more likely to drop out. Those who did well had a proven academic ability, a colleague-like relationship with their professors, and self-confidence. These three factors were interrelated: lack of professor support meant less selfconfidence which meant less likelihood of submitting manuscripts for publication which meant less self-confidence and less professor support (Dagg \& Thompson, 1988, p. 13).

Male students were also negatively affected. The subtle affirmation of the status quo made male students less likely to work collaboratively with female students and hampered their ability to take female colleagues seriously. It denied them the opportunity to benefit from the opinions and ideas of half of their classmates and reinforced stereotypical views (Hall \& Sandler, 1982, p. 3).

The "chilly climate" for female students also extended to female faculty and, thus, it also affected the female students. Sandler (1991) suggested that women faculty members were "devalued" by male professors, male students and, less often, by female students:

In mixed classes of graduate students, male students tend to be more aggressive when the class is taught by a woman. The men not only speak longer and more often than women students, but they interrupt the women students and the female professor more than they do when the class is taught by a male. . . The authority of women faculty may be challenged more often and more strongly. They are more likely to be asked about their credentials. ... Students may be more skeptical about the remarks made by women faculty (p. 7). 
Women in classes where a female professor was constantly criticized or challenged tended to internalize that message as a warning about their own future causing them to modify aspirations and adopt less assertive career behaviors. Women students made cognizant of "their own inadequacy and lack of authority" through the graduate school process became less likely to try for jobs and less able to challenge the existing circumstances (Dagg \& Thompson, 1988, p. 10). Steinem (1992) found that women with higher levels of education tended to be less assertive. Women working in factories were more likely to challenge the status quo than were their more formally educated counterparts.

The sexist language, belittling of female accomplishments, and lack of mentoring support for female students were even more pervasive when the women were studying in a male dominated discipline such as educational administration.

\section{Women in Educational Administration Programs}

In 1979-1980, 142 American respondents who were actively seeking administrative positions were surveyed (Edson, 1988). When the same people were resurveyed in 1984-1985, one-third had become principals. Many of these women enrolled in educational administration programs as a way to compensate for the lack of administrative experience available to them within the school system. Nearly all $(87 \%)$ felt that they had to become more qualified than men in order to be considered for administrative positions (p. 24).

The climate was not "chilly" for everyone. Many women in Edson's (1988) study reported encouragement, stimulation, and renewed self-confidence through the courses taken (p. 22). The programs with internships were considered especially valuable because they (a) provided practical experience, (b) allowed women to prove their capabilities and impress potential employers, and (c) helped women clarify their interests and focus their future directions (pp. 30-32).

Women in educational administration programs tended to be older than men, had more teaching experience, and were "more socially deviant" (Silver, 1976, p. 12). Silver found them to be more assertive than other women, and less likely to be categorized by existing stereotypes. Although the women were older, they had less financial support, came from lower positions in the school system and also aspired to lower positions after graduation (Marshall, 1984). This meant that, based on status already achieved, the men started the classes with more credibility than women - professors and other students were likely to value the opinions of a male former superintendent, for example, over those of a female former grade two teacher. 
Women feared that these attitudes would affect the recommendations professors wrote when they applied for jobs. Although educational administration departments claimed to support female candidates, the women felt that they did not follow through. Although departments worked to place their graduates, it was the male graduates who were obtaining the jobs (Edson, 1988, pp. 35-37). Those women who were supported by their professors tended to be "more passive and non threatening, or at least capable of appearing so" (Adkison, 1981, p. 323). Ironically, although unusual women were choosing educational administration, the profession was choosing the more "usual" women (Edson, 1988, p. 38).

Women students had positive experiences with women professors who transferred women's issues into the classroom instead of "chit-chat outside in the halls" (Edson, 1988, p. 37). However, women professors were often junior faculty without administrative backgrounds, therefore, lacking connections in the field. Female faculty in educational administration faced problems in establishing credibility and handling challenges from male students (Sandler, 1991). This lack of support was compounded by the perception, on the part of male students, that by treating women the same as men, the female faculty members were discriminating against them (p. 10).

Another problem for women in educational administration was "androcentric bias" in texts and other materials (Marshall, 1982; Shakeshaft, 1989, p. 111). Leadership roles have historically been filled by males, thus studies of leadership were usually based on male case studies and on male theories of good leadership. Shakeshaft and Hanson (1986), in an examination of the 1970's issues of the Educational Administration Quarterly, found that only $8 \%$ of the articles were authored or co-authored by women and that more than $62 \%$ of the authors used gender exclusive language. They found androcentric bias in ". . . problem selections and formulation, selection of samples, data collection procedures, and interpretation of results" (p. 86).

A replication of the Shakeshaft and Hanson study, using the articles published in the EAQ during the 1980's, found improvements in the most obvious areas, in that $29 \%$ of the articles were written by women and only $7 \%$ used gender exclusive language. However, other more subtle areas of bias remained much the same. The theories and instruments of research continued to be based on male experiences and the inclusive language used in the reporting masked the androcentric bias to make it appear less prevalent (Epp, Sackney \& Kustaski, 1994).

Shakeshaft (1989) cautioned that there was a fundamental error in any process which focused on changing women to make them more acceptable in a 
male world, rather than changing the world to make it more hospitable to all people (p. 127). She suggested some strategies to decrease the "chilly climate" while waiting for the world to change. These recommendations included both organizational and system changes. Organizational strategies were those aimed at recruiting more women, or providing them with intern experiences to increase visibility and experience. System changes would provide women with financial aid, increase the number of female educational administration professors, add courses to existing programs which would meet the needs of female students, and change the curriculum of existing courses to include women's experiences (Shakeshaft, 1989, pp. 125-134).

Some educational administration programs now include courses aimed at helping women overcome barriers (Calabrese \& Bartz, 1991; Chance \& Neuhauser, 1991; Pigford \& Tonnsen, 1990). These special courses are intended to develop and refine leadership skills and to provide a venue for women students to form a network for a continuing support group. Shakeshaft (1989) expressed frustration at the minimal effect that any institutionally implemented changes would have on the actions and attitudes of individual males - the use of sexist language, sexist jokes, and the concentration of androcentric subject matter (p. 131).

There can be little doubt that women in educational administration programs have faced more difficulties than have their male counterparts. However, the demographics of the gender balance in the classes continue to change. Women make up 53\% of university undergraduates and, although they are still in the minority $(45 \%)$ in other graduate programs, they are a majority in colleges of education (Government of Canada, 1992, p. 4). Female education students make up $70 \%$ of undergraduates, $67 \%$ of graduate students, and $58 \%$ of doctoral students in education (Pyke, p. 3). Now that female students outnumber males has the experience changed?

\section{Method}

The present study was undertaken to assess the current circumstances for women in educational administration programs. The instrument used was based on recommendations made in the literature. Students were first asked if specific statements were true for them, for example, did they have female advisors, access to special programs, financial assistance etc. They were then asked to identify the occurrence of specific experiences, using a seven point scale with the following descriptors: never, once or twice, sometimes, half the time, often, much of the time, and always. Questions were asked concerning inclusive 
language, course content, and various aspects of sexism and harassment. Finally, respondents were invited to describe any incidents which would illustrate their experiences in the program.

The intention was to survey one quarter of the female students from each institution in Canada which granted M.Ed. degrees in Educational Administration between 1989 and 1992. The most difficult part of this research was locating the women to be surveyed. Twenty-nine departments of Educational Administration or chairs of graduate programs were contacted to request the addresses of eligible students. Twenty-one universities responded, four were unable to participate because they did not have educational administration programs. Two others were prevented from participating by various policies and codes of ethics. That meant that students from 15 universities were contacted. The contact took different forms depending on the ethics requirements at the various locations. Seven institutions had policies which prevented them from furnishing names, but department heads or professors at these places volunteered to distribute the questionnaires to their current female students. Thus, there is no record of exactly how many students were surveyed in those situations. The other eight institutions provided lists of students. Surveys were sent to one quarter of the people listed by each of these institutions. Questionnaires were sent to as many as 25 students from some institutions, but most were represented by from between seven to fifteen students. Approximately 200 questionnaires were distributed, although cooperative individuals at the various institutions may have reproduced additional copies. Fifteen questionnaires were returned unopened because students had moved. Assessment here was based on 123 usable questionnaires, a response rate of $66.5 \%$. Although the sampling process may have been somewhat irregular, these findings represent the realities for these students and provide a substantive body of information on the experiences of women students.

In order to encourage honest and open responses, students were not identified by name or by institution, but judging from legible postmarks, responses were received from all provinces except Newfoundland and Prince Edward Island (P.E.I. has no graduate courses in Educational Administration). Surveys were returned with the following postmarks: Quebec - 24, Ontario - 24, B.C. 22, Saskatchewan - 13, Alberta - 9, Manitoba - 9, Nova Scotia - 8, New Brunswick -3 , unknown -12 . Most of the respondents $(76 \%)$ were currently enrolled in educational administration programs. Nearly $20 \%$ had completed their degrees. More than a third $(37.8 \%)$ were, or had been, administrators. Six percent were visible minorities. Although the question was not asked, many 
respondents volunteered the approximate ratio of men to women in their classes. Only three were in a minority, twelve others were more or less "even" and for seven, the women outnumbered the men.

\section{Interpreting Responses}

The questionnaires elicited specific data concerning entry into the program, program requirements, and experiences within the program. Respondents were also asked for general reflections which were used to (a) classify the respondents according to their perceived satisfaction with the program, (b) illuminate the statistical data, (c) provide a forum for other emerging issues, and (d) to document respondents' suggestions for improvement. Therefore, the format for reporting is divided into four sections: classification of respondents, interpretation of the data, issues arising from the comments, and respondents' suggestions for improvement. Quotations from respondents' comments are identified by a respondent number in parentheses following their statements:

\section{Classification of Respondents}

Respondents were requested to jot down any experiences or recall any incidents which would illustrate their experiences as women in educational administration programs. Over 100 of the 123 respondents filled in the comments section some with a few words, others with several typewritten pages.

Three respondents took offense to the questionnaire because they felt that it showed an anti-male bias: "This survey sounds so anti-male it borders on feminist paranoia. Get a life!" (Respondent 110). The same person volunteered this information:

I am a "Mrs."; not a "Miss" and I am sure as Hell not a "Ms." God I loathe that title! (110).

The second found the survey "degrading, narrow-minded and sexist!" (Respondent 53) and suggested that it was "out of date" because these were "70's issues". The third conceded that the world was still a male oriented place, but that was the way she liked it:

Don't push this feminist entrenched 'bologna'. I'm happy being a woman. I am comfortable being feminine in a male-oriented society (49).

The rest of the respondents could be divided into three categories - those who, to continue the metaphor, found the climate "warm", "moderate", or "chilly". 


\section{A Warm Climate}

A group of about 20 respondents expressed positive general feelings about the program and commented on the learning, the support, or the excitement of their experience $(77,87,31,39,119,26)$ :

I felt fortunate to be in a small friendly family in which many of my courses were taught by women (102).

\section{A Moderate Climate}

Another much larger group of around 50 respondents had good experiences; albeit, there were things they felt could be improved. They identified some lingering problems for women in educational administration programs and provided many of the suggestions concerning ways in which the program could be improved (Respondent 6, 108, 107, 104, 73, 2, 47, 19).

(My experience was) mostly very positive, (I) have rarely felt discriminated against ... (97)

Many of the "moderates" connected the treatment of women in society with their experience in educational administration. They felt the university could not be expected to be any more friendly toward women than school boards or society in general $(37,9,24,2,105,92,58,1,62)$.

I don't find that (this university) holds me back, rather it's the reality of our non-accepting, male dominated society that I am weary of (33).

Some in this group had not personally experienced any difficulties because they were women, but did recognize that that possibility existed for others. Several attributed their lack of difficulty to their own attitudes or abilities (Respondents 6, 74, 50, 120):

I have always presented myself in a professional manner and was always treated as such (8).

\section{A Chilly Climate}

A group of about 25 felt that the climate was still "chilly". They expressed concerns about their treatment in the program which took the form of varying emotions ranging from isolation and sadness to anger and a wish for retaliation $(117,116,60,72,56,90)$. Some of their quotes have been included to allow them to speak for themselves: 


\section{The Isolated}

(I) basically felt like a "fish out of water". The female perspective is not considered worthy of consideration (72).

As a woman in educational administration you often feel "schizophrenic". Your feminine "sense of being" is constantly "at war" with the functionalist, objectivist, quantification of what educational administration is. The values of "humanness" are swept under the carpet as "status quo" values of maleness are held high (67).

\section{The Saddened}

I'm tired and discouraged and frustrated by the inequities I view and experience. There is a need for sweeping changes in order to rectify the present situation (1).

\section{The Angry}

The atmosphere that permeates the entire faculty of education is one of sexism and the power of the "old boys network". The problem goes beyond the Ed Admin. program to the entire faculty and the entire university (90).

\section{Interpretation of the Data}

Data concerning entry into the program, program requirements, and experiences within the program were augmented by substantiating comments from participants' reflections on the program and suggestions for improvement. Table 1 shows the percentage of respondents who reported access to specific items identified by Shakeshaft (1989) and others as ways to encourage women in educational administration programs. Table 2 shows the percentage of respondents who responded in each category to specific questions. Sampling difficulties preclude generalization to the entire population, but these numbers may give some indication of the realities experienced by women students.

\section{Entry into the Program}

Why did these women decide to take educational administration classes? Less than half ( 55 people or $45.9 \%$ ) reported that they had been encouraged by anyone to take the program. Of these, most were encouraged by men (58.2\%), usually their husbands $(31 \%)$. Other encouragers, in order of frequency, were male or female principals $(33 \%)$, other family $(10.3 \%)$, other teachers $(8.6 \%)$, other administrators such as superintendents or directors $(6.9 \%)$, and other friends $(5.2 \%)$. 
Table 1

Availability of programs and resources recommended to enhance women's experiences in educational administration programs

Program or Resource

Internships

(Internships specifically for women)

Female Advisor

Female Mentors

Male Mentors

Mentors (Total)

Special Classes

Financial Assistance

(Financial Assistance specifically for women)

$\begin{array}{cc}\text { Available } & \begin{array}{c}\text { Not } \\ \text { Available }\end{array} \\ 10 \% & 90 \% \\ 1 \% & 99 \% \\ 18 \% & 82 \% \\ 10 \% & 90 \% \\ 21 \% & 79 \% \\ 31 \% & 69 \% \\ 14 \% & 86 \% \\ 18 \% & 82 \% \\ 5 \% & 95 \%\end{array}$

Some had been discouraged by comments from other teachers who told them that their families were more important than studies, or by parents and siblings who suggested that they had enough education already (respondent 73 ). Others (respondents 64,91 ) felt that they had been unable to obtain the necessary counseling to help them in making the decision or had been advised to try curriculum rather than administration $(61,75)$. They were told that the principalship was too demanding for women, especially women with families. Two other respondents had chosen not to continue in an administration program for that reason. They had decided, after a few classes, that administration would not be personally fulfilling $(9,85)$.

\section{Program Requirements}

These respondents reported little change to existing structures to accommodate the influx of women students. Only one reported any change in the entry requirements. Many others were emphatic that they would not want the requirements modified on their behalf $(8,87,50,13110)$ :

Giving "special" treatment would result in tension between men and women in classes (69).

I disapprove of treating females different in any way - an insult to my intellect (81). 
Table 2

Reported frequency (in percentiles) of aspects of women's experiences in educational administration programs based on 123 respondents from across Canada

\begin{tabular}{lcccccccc} 
& \multicolumn{2}{c}{$\begin{array}{c}\text { much } \\
\text { of the } \\
\text { Questions }\end{array}$} & $\begin{array}{c}\text { half } \\
\text { always }\end{array}$ & $\begin{array}{c}\text { time } \\
\text { of the } \\
\text { time }\end{array}$ & $\begin{array}{c}\text { once } \\
\text { some } \\
\text { times }\end{array}$ & $\begin{array}{c}\text { or } \\
\text { twice }\end{array}$ & never \\
\hline Were classes taught by females? & 0 & 5 & 2 & 14 & 11 & 36 & 32
\end{tabular}

Did professeurs use inclusive language?

$\begin{array}{lllllll}10 & 20 & 19 & 4 & 35 & 9 & 3\end{array}$

Were leadership theories studied based on male experience?

$\begin{array}{lllllll}2 & 37 & 21 & 4 & 11 & 2 & 0\end{array}$

Did you study possible differences in $\begin{array}{lllllllll}\text { male and female leadership styles? } & 1 & 4 & 2 & 2 & 23 & 34 & 34\end{array}$

$\begin{array}{lllllllll}\text { Did you study women leaders? } & 0 & 0 & 2 & 1 & 22 & 22 & 53\end{array}$

Did you study theories and research $\begin{array}{lllllllll}\text { reports written by women? } & 1 & 2 & 7 & 3 & 53 & 28 & 6\end{array}$

Were courses modified to reflect the $\begin{array}{llllllllll}\text { experiences of female students? } & 2 & 0 & 4 & 3 & 17 & 13 & 61\end{array}$

Did professors make sexist jokes in class?

$\begin{array}{lllllll}0 & 1 & 1 & 2 & 16 & 14 & 66\end{array}$

Did you hear professors make sexist jokes outside of class?

$\begin{array}{lllllll}0 & 0 & 1 & 1 & 11 & 10 & 77\end{array}$

Were you sexually harassed by anyone during your program?

$\begin{array}{lllllll}0 & 0 & 0 & 0 & 3 & 5 & 92\end{array}$

Were you made to feel you did not belong in the program because of gender?

$\begin{array}{lllllll}0 & 2 & 2 & 1 & 9 & 7 & 78\end{array}$

Were you advised to take more classes and do less research?

$\begin{array}{lllllll}2 & 2 & 1 & 0 & 6 & 2 & 87\end{array}$

Were you encouraged to use $\begin{array}{llllllll}\text { statistical research techniques? } & 9 & 8 & 14 & 5 & 21 & 13 & 30\end{array}$

Were you encouraged to use qualitative research methods?

$\begin{array}{llllll}12 & 16 & 7 & 28 & 13 & 17\end{array}$


Once in the program, only $13.9 \%$ of these students had been offered special programs. Some were able to take Women's Studies classes as an optional part of their programs (respondent $84,102,6$ ) and some educational administration programs included special interest courses such as "Gender Equity" (77), "Feminism in Education" (38) and "Women in Education" - which was taught by a man (122). Twelve students $(9.8 \%)$ had the opportunity to intern; in one case that program was intended specifically for women. One woman mentioned a program alteration which made it harder for women. The completion deadline had been shortened "to the detriment of working mothers, attending part-time" (36).

Some adaptations were provided, not by universities, but by school boards $(94,18)$. One principal reported that a group of them were provided with release time to take classes on Monday afternoons (94).

Twenty-one of these respondents $(17.5 \%)$ had received financial assistance. Of these, six received funding which was intended solely for the use of female students. Many women commented on the cost of daycare, tuition, commuting and books $(36,76,64,58,36,2)$. Others lamented the lack of other supports and commented on the difficulties of running a household, caring for children, teaching full-time, and often commuting as well $(76,79,17,109,111)$ :

The burden of family care still seems to fall on women ... Conversely, many of the men commented on how fortunate they were that their wives were "holding down the fort" and driving their children to various activities while they were occupied at class (76).

The males in the classes never faced the same obstacles as I did. They had wives to look after their children, help them with homework etc. to perform all the endless household tasks etc. (1)

Several knew women who had dropped out because the demands were too great (89).

In a few cases, other changes had been made to accommodate female students. One woman had the class meet in her living room instead of a classroom. Another had a course time changed to accommodate a number of working women in the course. Several students mentioned examples where time changes were made to accommodate everyone, male and female.

For several respondents there was rhetoric from administrators and professors supporting women in the courses, but nothing concrete was done $(12,75,7$, 59)

(The university) provided no support or understanding whatsoever; attitude was "too bad" (72). 


\section{Experiences Within the Program}

Advisors, Teachers and Mentors

Twenty-two (18\%) of 123 respondents had a female advisor for their research. One student reported that she had been assigned to a female advisor but had switched to a man because she didn't like this person's "anti-male stance or second class status" (Respondent 53). Although this attitude was expressed by only one student, it does reflect Sandler's (1991) finding that women professors have more difficulty establishing their authority and are likely to be "devalued". Other women were more positive about their female advisors:

Having a woman as my advisor, and a woman who was interested in and had studied in quantitative research methods also added a certain dimension to my studies I may not have experienced otherwise (102).

Thirty-seven (31\%) had a mentor. Fourteen of the mentors were females. Several sudents spoke of a desire to be mentored within the school system as well as at the university $(112,111,64,107,79,80)$.

Educational administration professors were predominately male $-32 \%$ of respondents had never had a female professor. An additional $47 \%$ had been taught by a female "once or twice" or "sometimes". This means that fewer than a sixth had women professors "half the time" or "often" (16\%). Six (5\%) were taught by women "much of the time" but none were taught exclusively by women. One in five professors is female (Government of Canada, 1992). Because Master's programs in Education cater to full-time teachers and principals, they are often offered during the evenings, on Saturdays, or during summer school. New professors and sessional lecturers are sometimes scheduled for these more inconvenient time slots which tenured and full professors are unwilling to fill. When compared to the $18 \%$ of respondents who were advised by women, these numbers may indicate that women are teaching courses but are not always serving as advisors to the research.

Inclusive Language The most obvious indicator of androcentric bias is the use of gender exclusive language. In one case it was the men who enforced the use of inclusive language:

All the male professors and students in my program went out of their way to not be sexist. They even caught some of us female students who didn't use inclusive language. I am sure that not all students have been as fortunate (102).

She was right; this experience was not the norm. Thirty years after inclusive language became a mandatory component in approved writing style 
manuals, it was still not necessarily a component of everyday classroom interaction. Respondents were particularly disturbed by the use of the pronoun "he" being used to denote an administrator (7). Only $10 \%$ of respondents reported that their professors had used inclusive language "all the time", while $35 \%$ circled "sometimes". Those who heard inclusive language "much of the time", "often" or "always" totaled $49 \%$. This means that nearly half of the respondents heard inclusive language used more than half of the time, but $3 \%$ had never heard any inclusive language at all.

Course Content Most respondents (60\%) reported that leadership theories studied in class were based on male experience "always", "much of the time," or "often". The possible similarities or differences between male and female leadership styles were discussed at least "once in a while" for two-thirds $(66 \%)$ of the respondents but for one third (34\%), it was never mentioned. Most $(61 \%)$ felt that their courses had not been modified to reflect the experiences of female students. One respondent mourned: "I sometimes longed for a female perspective on theories" (39).

When women's issues were discussed, they were usually brought to the class by the women themselves $(8,94,47,10,122)$ through their comments or presentations:

In the courses taught by men, the professors make no special effort to study women as educational leaders. They are, however, very receptive when women students introduce theories and reports by women. The seeds are there but we still have a way to go (10).

When it did surface, there were both positive and negative reactions. Many male professors and students made positive comments about how the women's presence "created a better dimension" to the course $(94,73,84,62)$. However, there were ugly experiences as well $(38,115,19,56,43)$. In several instances "experiences and perspectives of female style of leadership were not legitimated" (56) and sometimes the content about women focused on the negative (43). For example:

Male students groaned or verbally expressed their lack of patience about hearing women's issues expressed. In all cases when this feeling was given by males in the class, discussion ceased in favour of their feeling. One professor "blamed" the woes of education on women's ways of doing things (55).

One respondent reported that "some of the readings reflected the role of women in educational administration" (11), but in some cases this topic was purposefully avoided: 
The two male professors deliberately excluded the text chapter on "Women in Educational Administration". They denied that women have different experiences from men in their careers and adamantly refuted the "white male privilege" concept (60).

Research Methods There was no evidence that gender affected choice of research method. Most (87\%) were never counseled to take more courses and do less research. There was no real difference between the numbers being encouraged to use statistical research methods and the numbers being encouraged to pursue qualitative methods. A few women had negative experiences with professors who were unwilling to work with anything but quantitative research $(106,1)$ but others attributed their own growth to exposure to qualitative styles (102):

The best course I took was one on qualitative research. I recognized that women's experience is different. No other courses even paid lip-service to such an acknowledgment (66).

Sexism and Harassment Sexism is harassment. The women in this survey were first asked if they had heard sexist jokes, in and out of class, and then if they felt harassed. Two thirds $(66 \%)$ had never heard a sexist joke in the classroom; 14\% had heard them "once or twice;" and, 16\% "sometimes". Four respondents $(3.4 \%)$ were subjected to sexist jokes "much of the time" or "often". For example:

At the very first class in the program I was horrified when the teacher made a very sexist, in fact dirty, joke, but more than that, I was horrified at the extent to which other women laughed at it. That same teacher holds a senior position in the department and continued to antagonize sensitive women (29).

There were also a few sexist jokes told by professors outside of the classroom. Although $77 \%$ of respondents had never heard one told, $20 \%$ heard one "once or twice" or "sometimes". However, most did not consider themselves harassed. Nearly all (91.5\%) reported no harassment; $5 \%$ had been harassed "once or twice;" and, another 3\% circled "sometimes". One respondent reported that a male advisor "hit on" her to date him (56).

Most (79\%) were never made to feel that they did not belong in the program because of their gender. Some felt that way "once or twice" $(7 \%)$ or "sometimes" ( $9 \%$ ). Four percent (5 respondents) felt that way "half the time", "often", or "much of the time".

To summarize then, these women were not encouraged to pursue educational administration classes, and very few changes were made to the programs 
to support or encourage them. Although many of them had a few female teachers, even fewer had female advisors, and there was limited access to mentors. Some were able to take special classes which reflected the female experience, and some had opportunity to hear the female experience included in regular course content, but these were few and far between. Women who were leaders and theories about and by women were not very high profile in the curriculum. Most women were not made to feel that they were unwelcome in the classes; nor were they subjected to sexism in the form of harassment or dirty jokes. However, inclusive language was not very common. Overall, women were not so much harassed as excluded.

\section{Other Issues - Attitudes}

The issue of "attitudes" emerged from the comments and was complex as women commented on attitudes toward women students, as exhibited by male professors and students, as well as attitudes toward women professors as exhibited by both male and female students and male professors.

\section{Male Professors' Attitudes Toward Female Students}

Respondents were not specifically asked to comment on the attitudes of males professors towards them, but one third ( 34 of the 100 who included comments) made some reference to the way they had been treated by male professors.

Twelve of these were positive comments. Many stated that professors were fair in the treatment of both sexes $(8,77,87,50,9,2,31)$, sensitive to the equity issues (62), encouraging and supporting of women in their academic endeavors $(119,62)$, and open to women and their experiences (10). Professors were understanding, respectful and helpful $(109,95)$, and some professors made a point of using questioning techniques which would encourage female response (109).

Some women had both positive and negative experiences. They named specific male professors as being "particularly sensitive" or supportive while others were known to "give female students a hard time" $(120,7,62)$. Some professors were considered simply old fashioned in their attitudes (86):

Male teachers in the department were very much bound by the old patriarchal discourse (29).

In some cases women felt ignored and overlooked $(121,90,59)$ :

Male professors take less interest in female students. They are more attentive to the other males in the class and often pursue them for research projects (105). 
Others felt patronized, intimidated, or that their opinions were devalued by the professor's remarks $(101,86)$ :

Female students are unable to contribute as their opinions are dismissed, and at times ridiculed (72).

I feel that when I question an idea I'm seen as challenging, nagging, nit-picking etc. When men challenge, their status increases and they're seen as engaging in intellectual dialogue (116).

Several women felt that professors tried to make them change in order to "fit in" better. The problem was that women were in a no-win situation. Some professors wanted them to be more aggressive:

He put me down for not being more vocal and aggressive. When I asked for assistance he told me you either "had it or didn't" (121).

Others wanted them to be more docile:

One professor is obviously uncomfortable with women in the program and puts down those who are assertive and do not share his personal viewpoint (101).

For some women it was more than a sense of being devalued. They felt that some professors discriminated against women by (a) giving them lower marks than men, (b) rewarding inferior work that men did and having higher expectations for women, or (c) discriminating against women who chose to write about less traditional topics:

The presentations of males (were) far poorer than those of females, yet males (obtained) higher marks (7).

One gave lower marks to young women because, as he stated "They hadn't paid their dues" and so didn't deserve the same mark that an older male administrator would get (90).

A colleague of mine ... wrote a paper on women's ways of knowing and received a very low mark. Her professor told her that the research she cited was just a bunch of crack pot theories and not worthy of serious consideration (90).

Sometimes professors were challenged for their sexist attitudes by both male and female students (120). In one case, the respondent took the professor to task for his behaviour with a threat that she would switch out of his class if he did not improve. In her words: "He was astounded at this behavior and did change - although with difficulty. Chauvinism is alive and doing well" (15). 


\section{Male Students' Attitudes Toward Female Students}

Male students exhibited a similar range of attitudes toward female students. Many were supportive, understanding, and encouraging $(69,19,22)$, and male students appeared to be "more accepting of the new views than the male professors" (86). Some women, however, felt that the men were overly competitive $(70,79)$ and "dominated discussion" (101). There was too much "male puffery which was artificial and counter-productive" (116). "Men talk more often, at greater lengths, in large groups with louder voices" (116) and will interrupt women when speaking $(59,35)$.

Men did not want to talk about "women's issues" such as affirmative action $(59,55)$, but several respondents $(55,68,35,122,79)$ noticed that men were becoming concerned about it as they made comments about tokenism and women taking unfair advantage.

\section{Attitudes Toward Female Professors}

Respondents commented on attitudes toward female professors from all perspectives - their own perceptions, the perceived attitudes of male professors toward female professors, and male students' responses to them. Female students usually praised and thanked female professors for their approach to teaching $(102,15,13,121)$ and their research perspectives $(107,102)$ :

(She) is most supportive of women, an excellent role model and treats women and men equally (119).

There were, however, complaints about some who were "on a feminist power trip" and made both males and females in the class uncomfortable $(82,49,53)$. One was said to be "very demanding regarding the workload" (41). Some had trouble with other women's brands of feminism:

Feminism is a way of life for myself and my daughters, for this lady it was her excuse for a very bleakly pessimistic, blame-laying attitude towards life (38).

Male students were accused, by female students, of trying to intimidate female professors (70) or to patronize them (86). Male professors also undermined female professors' authority (43). On one faculty, there were two women:

The traditional male-in-everything-but-gender professor is accepted, lauded and bragged about by other (male) faculty. The feminist scholar is never mentioned. She's untenured and teaches the "women's course" (116). 
Other women students noted the status of the female professors:

It was also unfortunate that the one professor in my program who was superbly organized, stimulating and current, remained a "sessional lecturer" (Respondent 86).

Although many women found that there were positive attitudes toward them, there were male professors who made women feel unwelcome and male students who ignored them. Women students were generally positive about their female professors, but they witnessed some devaluing of female professors by male professors and students.

\section{Improvement Tactics}

The women's responses to the request for suggestions to improve the recruitment and retention of women in educational administration programs centered around course content, course instructors, and program changes. There were also strong recommendations for change in the school systems themselves.

\section{Course Content}

Thirty respondents suggested changes to course content to reflect issues relevant to women in educational administration. Most suggested women's issues as a component of existing courses and felt that all students, male and female, should be exposed to them $(72,91,104,43,116)$ :

The entire educational system needs to be re-conceptualized [and] incorporate the lives and experiences of women. Education consists of an initiation into an existing body of knowledge. This existing body of knowledge is (presently) defined by males (1).

They suggested that more use be made of research about and by women $(33,6,74,41)$ and that required readings should include references to positive contributions made by women's ways of administering $(79,6,56,27,19,72$, $121,104)$. The provision of a bibliography of these resources would help (76). The readings could be alternated between those by men and those by women (54). Professors could use alternate methods of teaching, such as role playing of conflict management (73), case studies comparing male and female ways of responding to situations (26), and class sharing sessions to include input from the female students (36). Some suggested that female administrators be invited to speak to classes about the special issues faced by women administrators $(33,6,73)$. Others suggested that special seminars $(67,82)$, panel discussions (73), and speaker series (73) be offered to augment course content. Many felt 
that special courses on women's issues should be made available $(97,73,77$, $67,36)$ and that these should include assertiveness training $(47,69)$.

Some of the suggestions would require collaboration. One student wished for cooperative learning groups rather than competition for marks (67). Another wanted collaboration and sharing among different universities across the country to make "dynamic women in educational administration" available to all (107).

\section{Course Instructors}

The inclusion of women's issues in course content would be much easier and more effective if done by sympathetic people. Respondents recognized that these materials, in the wrong hands, would be damaging (6). Many respondents suggested that universities employ more female professors $(84,111,59,14,74$, $79,67,72)$ to provide more role models $(68,103,1)$, and some specified that institutions should "demonstrate equality by striving for an equal distribution of males and females on the faculty" $(97,86)$.

Some wanted specific types of female professors, those who are "womenaffirmative, but not necessarily aggressive" (39) or "career women - mothers and teachers who can appreciate how difficult it is to juggle both a career and a family" (7). They did not want "consultants" (54) or those who have "bought into the traditional way of being and doing" (116).

For others, the gender of the professor was immaterial. Some wanted all existing faculty replaced with "practicing administrators ... (who would be) current, stimulating instructors" (86) because "female students are busy people. We have no time for lazy professors or disorganized classes" (67).

For male professors, respondents suggested "awareness opportunities" (38) "seminars, similar to cross cultural training . . . to heighten awareness and understanding of needs" (72). It was also suggested that professors could use training on teaching adult learners (106).

\section{Program Changes}

Many respondents suggested that the universities could serve as the basis for a network which would provide contacts in the school systems for beginning administrators and formal and informal mentorships $(50,76,64,107)$. Students could "shadow" practicing administrators (79), or at least have an experienced administrator to consult with (104). Students could be better supported if they went through with a cohort of other students (108) or were matched with senior graduate students (43) who could provide information about classes and job opportunities (58). 
Women suggested scheduling aimed at improved access for women with children $(72,88,60)$. One wanted courses offered during the day so that she would not have to pay baby-sitters for night classes (56). There could be more flexible deadlines $(66,91,17)$ and relaxed residency requirements $(76)$, or arrangements made with school systems to allow time off work to attend classes $(17,104)$. Alternate delivery methods such as teleconferences (97) and off campus courses were suggested to reduce the need to commute (66).

The issue of alternative scheduling was connected to financial need. Financial assistance would encourage women to take the full-time program (86). Financial assistance was suggested by many respondents $(67,64,17,2$, $12,76)$, especially in connection with daycare needs $(36,56,87,12,35,59)$. Other suggestions were to provide more assistantships (35) and to allow for the payment of fees in installments (60).

\section{Change the School Systems}

Although changes within the school systems and society at large could be considered beyond the scope of this research, respondents' demands for change could not be ignored because they were so pervasive. Respondents felt that if women were encouraged from within the system they would be willing to take the courses and eventually the jobs $(70,20,37,6810,58,23,105,1,92,2101)$. Many were pessimistic about both the job market (68) and chances for promotion to higher positions such as directors and superintendents (61). Several respondents were obtaining an M.Ed. in administration but had no intention of ever using it, because they did not think that being an administrator was worth the hassle. One suggestion was to "make the principal's job more human so women will want to do it" (24).

\section{Conclusions}

This study was done to assess the present realities of women's experiences in graduate programs in Educational Administration. Is the "chilly climate" warming or has it continued in spite of the influx of female graduate students in educational administration programs? The metaphor of the half full glass arises in attempts to answer this question. Should we be rejoicing that nearly half of the students heard inclusive language at least half of the time, or should we mourn the fact that one third of the students were hearing no inclusive language at all?

To dwell on the positive - a substantial number of respondents were among those experiencing a warm or at least a moderate climate. Some of the statistics could be considered positive: one in ten of the respondents were doing intern- 
ships; one in five had female professors about half the time; nearly one in five had female advisors or were getting financial assistance; and, one in three had a mentor. Only a quarter heard sexist jokes in class, and even fewer heard sexist jokes in the halls. The good news is that for many this representative statement was true:

I did not feel threatened or inferior in any way during the class time (39).

For many women in this study, however, the experience had not been positive, and there are few gains noted in areas such as course modification and financial aid. The comments of many mirrored anger and isolation, and there were too few women professors serving as role models and advisors.

Issues which were identified in the literature were reflected in this study. Some male (and female) students and professors continued to devalue female professors. Women were counseled out of administration into curriculum. Sexist language continued to discourage or isolate female students. Women in classes continued to be ignored, insulted, or even penalized because of their gender. As one respondent commented:

"Brown nosing" and the "old boys club" are alive and well in the educational administration department (7).

Perhaps the most disappointing aspects were found in the belief that sexism is rampant everywhere, not only in specific departments or portions of society. As one student suggested:

I have found the sexism . . . to be subtle but pervasive, but in all fairness the educational administration staff is no worse than any other graduate level department in education (105).

The last word goes to another respondent who was able to sum up the differences between individual experiences and the collective reality:

I think we trust women we know very well and treat them like

"exceptions", but we don't trust women in general (23).

Most of these women did not want to be the exceptional woman who managed to "make it" in a male dominated society. They wanted to be able to grow and develop through the graduate program on a par with their peers, male and female. 


\section{References}

Adkison, J. (1981). Women in school administration: A review of the research. Review of Educational Research, 51(3), 311-343.

Calabrese, R., \& Bartz, D. (1991). Improving educational administration programs. Journal of School Leadership, l(4), 351-362.

Calas, M., \& Smircich, L. (1992). Re-writing gender into organizational theorizing: Directions from feminist perspectives. In Reed, M., \& Hughes, M. Rethinking organization: New directions in theory and analysis, chapter 12 London: Sage.

Chance, E., \& Neuhauser, M. (1991). Preparing women and minorities as rural school administrators. Rüral Educator, 12(2), 1-5.

Dagg, A., \& Thompson, P. (1988). MisEducation: Women \& Canadian universities. Toronto: OISE Press.

Edson, S. (1988). Pushing the limits: The female administrative aspirant. Albany: State University of New York Press.

Epp, J., Sackney, L., \& Kustaski, J. (1994). Androcentric bias in the Educational Administration Quarterly. Educational Administration Quarterly 30(4).

Government of Canada. (1992). Profile of higher education in Canada. Ottawa: Department of the Secretary of State, Minister of Supply and Service, Canada.

Hall, R., \& Sandler, B. (1982). The classroom climate: A chilly one for women. Project on status and education of women. Washington: Association of American Colleges.

Marshall, C. (1984). Men and women in educational administration programs. Journal of NAWDAC, 48(1), 3-12.

Pigford, A., \& Tonnsen, S. (1990). The women's institute: Preparing women to deal effectively with sexism and racism in school administration. Teaching Education, 3(1), 87-91.

Pyke, S. (1991). Gender issues in graduate education. Faculty of Graduate Studies. Calgary: University of Calgary.

Sandler, B. (1991). Women faculty at work in the classroom, or, why it still hurts to be a woman in labor. Communication Education, 40(1), 6-15.

Shakeshaft, C. (1989). Women in Educational Administration. Newbury Park: Sage.

Shakeshaft, C., \& Hanson, M. (1986). Androcentric bias in the Educational Administration Quarterly. Educational Administration Quarterly, 25(1), 68-92.

Silver, P. (1976). Women in Educational leadership: A trend discussion. Columbus, $\mathrm{OH}$ : University Council for Educational Administration.

Steinem, G. (1992). Revolution From Within. Boston: Little, Brown \& Co. 